\title{
Economic Growth and Income Disparity between Regencies/Cities in West Java Province
}

\author{
By: \\ S. Lestari ${ }^{1)}$, Ratna Setyawati Gunawan ${ }^{2)}$ \\ ${ }^{1,2)}$ Faculty of Economics and Business, Universitas Jenderal Soedirman \\ ${ }^{2)}$ Email: gunawan.ratna@gmail.com
}

\begin{abstract}
This study analyzes the relationship between economic growth and income inequality between regions in the Province of West Java throughout 2005 to 2014 by using analytical tools based on calculations from the Williamson Index, Entropy Theil Index, Product Moment Correlation, and trend analysis. Based on the calculation of the Williamson Index and Entropy Theil Index found that the income gap between districts in West Java Province is high. The average Williamson Index value is 0.628 and the Theil Index Entropy is 1.421. The Kuznet Hypothesis (inverted $U$ curve) was not proven in West Java Province during 2005 to 2014, and based on an analysis of the trend of income inequality between districts shows an increasing trend.
\end{abstract}

Keywords: Income Disparity, Economic Growth, Kuznets Hypothesis.

\begin{abstract}
ABSTRAK
Penelitian ini menganalisis hubungan antara pertumbuhan ekonomi dan ketimpangan pendapatan antar wilayah di Propinsi Jawa Barat sepanjang tahun 2005 sampai dengan 2014 dengan menggunakan alat analisis berdasarkan perhitungan dari Indeks Williamson, Entropi Theil Index, Korelasi Product Moment, dan analisa trend. Berdasarkan perhitungan Indeks Williamson dan Entropi Theil Index ditemukan bahwa kesenjangan pendapatan antar kabupaten di Propinsi Jawa Barat tergolong tinggi. Rata-rata nilai Indeks Williamson sebesar 0.628 dan Entropi Theil Index sebesar 1.421. Hipotesis Kuznet (kurva U terbalik) tidak terbukti di Proppinsi Jawa Barat sepanjang tahun 2005 sampai dengan 2014, dan berdasar analisa trend ketimpangan pendapatan antar kabupaten menunjukkan trend yang meningkat.
\end{abstract}

Kata Kunci: Ketimpangan Pendapatan, Pertumbuhan Ekonomi, dan Hipotesis Kuznet.

\section{INTRODUCTION}

Regional economic development is not always equal, some regions achieve high economic growth, while other not. The main objective of economic development is not only to create the highest growth, but also to reduce poverty, income inequality and unemployment. Job opportunities for residents or the community will provide income for the needs of life.

Many theories predict that regions who do not experience the same progress with other region were caused by a lack of resources and supporting infrastructure such as roads, transportation, electricity, telecommunication, and financial. As in Chintrakarn et al. (2012) by using panel cointegration analysis found that there is negative long-run relationship in foreign direct investment and income inequality in across state the United States of America. Ouyang and Fu (2012) study, who emphasize the importance of investment, found that there is positive impact of inter-regional spillover in China from Foreign Direct Investment (FDI) on economic growth of inland cities. Research by Sahoo and Dash (2009) also supporting the view that infrastructure development plays important 
role in growth. Yet, what they found is pretty interesting that the impact of infrastructure development to economic growth is unidirectional.

Today economics theory have seen development not only increased in output. For example, Fleisher et al. (2010) who observed the regional inequality in China also found that China's regional growth patterns depends on physical, human, and infrastructure capital where capital investment give higher return in more developed region, whereas human capital investment in less developed area give more contribution to reduction regional inequality. Moreover, for developing countries, according to Hanushek (2013), investment in human capital is far more important to ensure long-run economic performance. Even, regional development study has go further that combined life quality criterion to ensure regional development. For example, study by Pittau et al. (2010) try to investigate on how economic variable affect regional income disparities based on life satisfaction criterion. Ramos (2014) also tried to identify the relationships between individual well-being (happiness) and inequality. He found that there are negative relationship between income inequality and individual well-being.

Our study is try to find out the relationships between economic growth and inter regency income disparity in West Java Province in year 2005 to 2014 using Williamson Index, Entropi Theil Index Calculation, Product Moment Correlation Analysis by Pearson, and Trend analysis.

West Java is one of the provinces that has the advantage and strategic role both in terms of geographic and economic side. In terms of geographic, West Java Province bordering the Special Capital Region of Jakarta as the center of growth, the center of government, and the national economy which is used as a market, financial center, capital and technology development. In terms of economic, West Java Province is the third largest GRDP compared to other provinces in Java, as can be seen in Table 1.

Table 1. Gross Regional Domestic Product (GDP) on the Basis of Constant Prices According to Provinces on Java Island 2011-2014 (Billion Rupiah)

\begin{tabular}{|c|c|c|c|c|c|}
\hline \multirow{2}{*}{ Province } & \multicolumn{4}{|c|}{ Year } & \multirow{2}{*}{ Average } \\
\hline & 2011 & 2012 & 2013 & 2014 & \\
\hline Jakarta & $1,147,558$ & $1,222,527$ & $1,297,195$ & $1,374,348$ & $1,260,470$ \\
\hline West Java & 965,622 & $1,028,409$ & $1,297,195$ & $1,148,948$ & $1,059,141$ \\
\hline Central Java & 656,268 & 691,343 & 726,899 & 766,271 & 710,195 \\
\hline Yogyakarta & 680,490 & 71,702 & 75,637 & 79,557 & 73,736 \\
\hline East Java & $1,054,401$ & $1,124,464$ & $1,192,841$ & $1,262,700$ & $1,158,602$ \\
\hline
\end{tabular}

From Table 1, it can be seen the comparison of Gross Regional Domestic Product (GRDP) between provinces in Java Island. It shows the comparison of the GDP of West Java province during the period 2011 to 2014 from year to year has a large GDP value and occupies the third position after DKI Jakarta and East Java Provinces. The GRDP of West Java Province tends to increase over the past four years, this illustrates that in the West Java Province there has been a development process as can be seen in the level of economic growth.

GRDP value cannot be used to describe the level of prosperity because each region has a very different population, thus even though the West Java Province's GRDP is greater than that of Central Java Province, this condition cannot be interpreted as the level of prosperity of the population of West Java Province higher than Central Java. Then to measure the level of prosperity we use per capita GRDP which is the average income of an area's population. The following Table 2 shows per capita GRDP growth rate based on the constant price of 2010 according to the province in Java Island in 2011 to 2014 
Table 2. Growth Rate of Gross Regional Domestic Product (GRDP) Per Capita at Constant 2010 Prices According to Provinces in Java Island, 2011-2014 (Percent)

\begin{tabular}{lccccc}
\hline \multirow{2}{*}{ Province } & \multicolumn{5}{c}{ Year } \\
\cline { 2 - 5 } & 2011 & 2012 & 2013 & 2014 & \\
\hline Jakarta & 5.51 & 5.34 & 4.96 & 4.84 & 5.16 \\
West Java & 4.78 & 4.82 & 4.70 & 3.49 & 4.41 \\
Central Java & 4.40 & 4.47 & 4.30 & 4.60 & 4.44 \\
Yogyakarta & 3.94 & 4.11 & 4.24 & 3.96 & 4.06 \\
East Java & 5.66 & 5.90 & 5.37 & 5.18 & 5.52 \\
Banten & 4.53 & 4.40 & 4.76 & 3.19 & 4.17 \\
\hline Total & 4.64 & 4.67 & 4.30 & 3.81 & 4.34 \\
\hline Source: Indonesian Central Bureau of Statistics (BPS), 2016
\end{tabular}

From Table 2, it can be seen that in the last four years East Java, DKI Jakarta, West Java, Banten and Central Java provinces have a high average per capita GRDP growth rate in Java. Special Province of Yogyakarta has the lowest growth among the other five provinces. West Java Province has a high growth rate in Java Island at 4.41 percent. Economic growth in West Java Province experienced fluctuating growth from year to year. Based on the data in Table 2 which shows the rate of economic growth in 2011 of 4.78 percent, an increase in 2012 was 4.82 percent. In 2013 despite experiencing a decline but not so large to 4.70 percent, which was followed by a decline back in 2014 to 3.49 percent.

However, West Java Province even have high average GRDP per capita growth rate, still has face some problems, one of the problem the existence of inequality. As seen in Table 3, it can be indicated by the value of Gini index in Java during 2011 to 2014.

Table 3. Gini Ratio Province in Java Island 2011-2014

\begin{tabular}{lccccc}
\hline \multirow{2}{*}{ Province } & \multicolumn{5}{c}{ Year } \\
\cline { 2 - 5 } & 2011 & 2012 & 2013 & 2014 & Average \\
\hline Jakarta & 0.44 & 0.42 & 0.43 & 0.43 & 0.43 \\
West Java & 0.41 & 0.41 & 0.41 & 0.41 & 0.41 \\
Central Java & 0.38 & 0.38 & 0.39 & 0.38 & 0.38 \\
Yogyakarta & 0.40 & 0.43 & 0.44 & 0.42 & 0.42 \\
East Java & 0.37 & 0.36 & 0.36 & 0.37 & 0.37 \\
Banten & 0.40 & 0.39 & 0.40 & 0.40 & 0.40 \\
\hline Source: Indonesian Central Bureau of Statistics (BPS), 2016
\end{tabular}

From Table 3, the Gini index of West Java Province over the year experienced stagnation and was ranked third in Java by 0.41 . DKI Jakarta Province had the highest Gini Index of 0.43 and DI Yogyakarta 0.42 percent. Judging from the high economic growth rate of West Java with a per capita GRDP growth rate of 4.41 percent and a high Gini index value of 0.41 , it is indicating there is a high inequality of income distribution in the province.

For example, Bekasi, one of major city in West Java Province, has the highest per capita GRDP of Rp 68.915.000 while Cianjur Region has the lowest per capita GRDP of Rp 12.831 .000 (as seen in Table 4). Per capita GRDP data in Table 4 shows that the level of welfare in West Java Province is unequal because there are only a few districts/cities that have high per capita GRDP, while other regions have a much lower per capita GRDP. West Java Province is border to border with DKI Jakarta Province, which is the Indonesia's capital city, and so it affects the rate of development and economic growth of regencies/cities that adjacent to DKI Jakarta or the northern region of West Java Province. Relatively, districts / cities in the northern part of West Java Province are more advanced compared to districts / cities in the southern region of West Java. 
Table 4. Gross Regional Domestic Product (GRDP) per Capita of West Java Province by Regency/City in 2014 (Thousand Rupiah)

\begin{tabular}{clc}
\hline No. & Regency/City & Per Capita GRDP \\
\hline 1 & Bogor Regency & 28,378 \\
2 & Sukabumi Regency & 16,914 \\
3 & Cianjur Regency & 12,831 \\
4 & Bandung Regency & 21,992 \\
5 & Garut Regency & 14,680 \\
6 & Tasikmalaya Regency & 13,548 \\
7 & Ciamis Regency & 17,671 \\
8 & Pangandaran Regency & 19,011 \\
9 & Kuningan Regency & 14,258 \\
10 & Cirebon Regency & 15,616 \\
11 & Majalengka Regency & 16,325 \\
12 & Sumedang Regency & 19,747 \\
13 & Indramayu Regency & 40,298 \\
14 & Subang Regency & 17,658 \\
15 & Purwakarta Regency & 49,957 \\
16 & Karawang Regency & 68,915 \\
17 & Bekasi Regency & 72,844 \\
18 & Bandung Barat Regency & 19,049 \\
19 & Bogor City & 28,235 \\
20 & Sukabumi City & 25,844 \\
21 & Bandung City & 69,868 \\
22 & Cirebon City & 49,430 \\
23 & Bekasi City & 24,267 \\
24 & Depok City & 21,478 \\
25 & Cimahi City & 35,524 \\
26 & Tasikmalaya City & 20,792 \\
27 & Banjar City & 16,680 \\
\hline Ince: Indonesian Central Bureau of Statistics (BPS), 2015
\end{tabular}

Districts/cities that have high per capita income were located in the northern part of West Java, which are close to centers of economic growth, such as Bekasi Regency, Bandung City, and Karawang Regency where it is the area for industries clusterization and a highly developed service sector and tourist attractions.

Based on the description above, the background of this research is that West Java Province has high economic growth in the third position in Java Island but also has a high Gini index value of 0.41 which indicates a high inequality.

\section{RESEARCH METHOD}

We use survey method for this research and It was conducted in the area of West Java Province, which consists of 18 districts Bogor, Sukabumi, Cianjur, Bandung, Garut, Tasikmalaya, Ciamis, Pangandaran, Kuningan, Cirebon, Majalengka, Sumedang, Indramayu, Subang, Purwakarta, Karawang, Bekasi, and 9 cities: Bogor, Sukabumi, Bandung, Cirebon, Bekasi, Depok, Cimahi, Tasikmalaya, Banjar.

Many previous research that study and examine regional inequality uses different measurement such as in Jenkins (2009) who examine British income inequality in 1994/1995 and 2004/2005 using Generalized Entropy (GE), Cornia (2010) that reviewed the declining trend of income inequality in Latin America using Gini Coefficients, Huang and Leung (2009) that tried to compare the measurement of regional inequality index between Coefficients of Variation (CV) and 
Hoover Concentration Index (Cl), and many other study like Iswanto (2015), He et al. (2010) that also use combined Location Quotient (LQ) and Lorenz Curve analysis.

To find out the size of the level of inequality between districts/cities in West Java Province our study used Williamson Index and Theil Entropy Index. Calculation of the level of inequality was carried out during the 10 years period (2005-2014) which included 18 districts and 9 cities. The calculation basis used is to use per capita GRDP in relation to the total population of each regency/city in West Java Province. Williamson Index criteria are between zero and one (0-1) if the Williamson Index number is smaller, then it shows that the inequality is getting smaller or in other words the more uneven. Likewise, if the Williamson Index is getting bigger or closer to one then it indicates a widening inequality or increasingly unequal income, while Theil's Entropy Index does not have an upper or lower limit, only if the greater the value, the more unbalanced and the smaller the value more evenly distributed. And last, to find out the tendency of the level of per capita GRDP inequality between districts / cities in West Java Province, the linear quadrant trend was used the least.

Then, to find out the relationship between economic growth and inequality of income distribution, Pearson's correlation analysis was used. It is said to be correlated if one variable changes followed by another variable changes.

\section{RESULT AND DISCUSSION}

\section{Inequality of Income Distribution between Regencies/Cities in West Java Province}

The calculation results show the average Williamson Index in West Java Province during the period of 2005 to 2014 is known to be 0.628 which means that the level of inequality between Regencies / Cities in West Java Province is included in the criteria of high inequality, because the average Williamson Index> 0, 5. It can be concluded that the difference in GDP per capita income between districts / cities is relatively high. Thus the hypothesis that states the level of inequality between districts / cities in West Java Province is included in high inequality can be accepted.

The calculation results show the average Entropy Index in West Java Province during the period of 2005 to 2014 is known to be 1.421. Theil's Entropy Index does not have an upper and lower limit, if the greater means to show more imbalance, the smaller the index, the lower the inequality or the more equitable. Based on the results of the Theil Entropy Index analysis in line with the Williamson Index, it means that the level of inequality between Regencies / Cities in West Java Province is relatively high, therefore it can be concluded that the hypothesis which states that the level of inequality between Regencies / Cities in West Java Province is included in high inequality criteria can be accepted. The decrease and increase in inequality that occurs between districts / cities is caused by the ability of each different region, different natural resources in each district / city, labor migration that is too centralized in urban areas, capital movements, the ever increasing population and local government policies in equity development.

\section{Analysis of the Trend of Income Inequality between Regencies/Cities in West Java Province in 2005-2014}

Our calculation of the trend of inequality income distribution with the least squares method has obtained the equation of the straight line $Y=0.62816+0.017633 \mathrm{X}$, for the Williamson Index and for Theil Y Entropy Index $=1.42079+0.012612 X$. From the trend equation, it can be seen that the income line inequality of Williamson Index and Theil Entropy Index in 2005 to 2014 shows a positive trend, indicating that income inequality has increased from year to year. A value in the Williamson Index trend is 0.628 which means that in the initial year it is assumed that the income inequality value is positive 0.628 and $b$ value of 0.0294 illustrates that every one year there is an increase in income distribution inequality of 0.029 .

The value of a in the Theil Entropy Trend Index is 1.420 meaning that in the initial year it is assumed that the Theil Entropy Index inequality value is 1.420 and the b value of 0.022 illustrates that in each year there is an increase in income distribution inequality of 0.022 . Thus the hypothesis that states the level of income inequality between districts / cities in West Java Province shows high 
inequality and the trend of income inequality between districts / cities in West Java Province is increasing.

\section{The Relationship between Economic Growth and the Level of Inequality}

The results of Pearson's correlation calculation show that the correlation coefficient is 0.380546 and 0.319583 , so that it is included in the positive correlation and the correlation coefficient is low, this indicates that if economic growth rises it causes inequality to rise, on the contrary if growth falls then inequality also will go down. This is because there is a trade-off between economic growth and equity, where local governments tend to concentrate more on increasing growth, thus ignoring equity.

\section{Proof of Kuznets Hypothesis (Inverted U Curve)}

A well-known hypothesis from Simon Kuznets stated that in the early stages of economic growth, inequality tends to deteriorate and at the next stage inequality decreases, but at one time there will be an increase again and finally increase again and eventually decline again, so that it can be said that the event is repeated. In this study at the initial stage of growth inequality is improving and in subsequent stages of inequality is increasing, but at a time there will be a decrease in inequality again and eventually will increase again, so that the event can be said as repetitive. This is contrary to the Kuznets hypothesis, so in this study Kuznets hypothesis does not apply.

The tendency of increasing inequality shown by the Williamson Index and Theil Entropy Index shows the ineffectiveness of the Kuznets hypothesis in districts / cities in West Java Province. Although there is economic development that continues to increase positively but does not reduce the level of inequality in the community of West Java Province.

\section{CONCLUSION AND RECOMMENDATION}

The conclusion that can be drawn from our research is as follows. First, districts/cities in West Java Province during 2005 to 2014 are included in the criteria of high inequality as we have seen from the results of the average Williamson index calculation and Theil Entropy Index. Second, there are positive and increasing trends of income inequality between districts/cities in West Java Province during 2005 to 2014 period. Third, Kuznets Hypothesis (the inverted U curve) did not statistically proven in the Province of West Java during 2005 to 2014.

\section{REFERENCES}

Chintrakarn, P., Herzer, D., and Nunnenkamp, P. (2012). FDI and income inequality: Evidence from a panel of U.S. States. Economic Inquiry, 50(3), 788-801.

Cornia, G. A. (2010). Income distribution under Latin America's new left regime. Journal of Human Development and Capabilities: A Multi-Disciplinary Journal for People-Centered Development, 11(1), 85-114.

Fleisher, B., Li, H., Zhao, M. Q. (2010). Human capital, economic growth, and regional inequality in China. Journal of Development Economics. 92. 215-231.

Hanushek, E. A. (2013). Economic growth in developing countries: the role of human capital. Economics of Education Review, 37, 204-212.

Huang, Y., and Leung, Y. (2009). Measuring regional inequality: A comparison of coefficient of variation and hoover concentration index. The Open Geography Journal, 2, 25-34.

He, S., Wu, F., Webster, C., and Liu, Y. Poverty concentration and determinants in China's urban lowincome neighborhoods and social groups. International Journal of Urban and Regional Research, 34(2), 328-349. 
Iswanto, D. (2015). Ketimpangan pendapatan antar kabupaten/kota dan pertumbuhan ekonomi di Propinsi Jawa Timur. Signifikan, 4(1), 41-66.

Jenkins, S. P. (2009). Distributionally-sensitive inequality indices and the GB2 income distribution. Review of Income and Wealth, 55(2), 392-398.

Ouyang, P., and Fu, S. (2012). Economic growth, local industrial development and inter-regional spillovers frome foreign direct investment: Evidence from China. China Economic Review, 23, 445-460.

Pittau, M. G., Zelli, R., and Gelman, A. (2010). Economic disparities and life satisfaction in Europe regions. Social Indicator Research, 96(2), 339-361.

Ramos, X. (2014). Inequality and happiness. Journal of Economics Surveys, 28(5), 1016-1027.

Sahoo, P., and Dash, R. K. (2009). Infrastructure development and economic growth in India. Journal of the Asia Pacific Economy, 14(4), 351-365. 